\title{
How climate change can affect the distribution range and conservation status of an endemic bird from the highlands of eastern Brazil: the case of the Gray-backed Tachuri, Polystictus superciliaris (Aves, Tyrannidae)
}

\author{
Diego Hoffmann ${ }^{1,4}$, Marcelo Ferreira de Vasconcelos $^{2}$ \& Rogério Parentoni Martins ${ }^{3}$ \\ ${ }^{I}$ Departamento de Ciências Agrárias e Biológicas, Universidade Federal do Espírito Santo, Rod. BR 101 \\ Norte, KM 60, Bairro Litorâneo, CEP 29932-540, São Mateus, ES, Brazil. \\ ${ }^{2}$ Museu de Ciências Naturais, Pontificia Universidade Católica de Minas Gerais, Avenida Dom José \\ Gaspar, 290, Prédio 41, Coração Eucarístico, CEP 30535-610, Belo Horizonte, MG, Brazil. \\ ${ }^{3}$ Departamento de Biologia, Universidade Federal do Ceará, Centro de Ciências, Avenida da Universidade, \\ 2853, CEP 60020-181, Fortaleza, CE, Brazil. \\ ${ }^{4}$ Corresponding author: Diego Hoffmann, e-mail: diego_hoffmann@hotmail.com
}

HOFFMANN, D., VASCONCELOS, M.F., MARTINS, R.P. How climate change can affect the distribution range and conservation status of an endemic bird from the highlands of eastern Brazil: the case of the Gray-backed Tachuri, Polystictus superciliaris (Aves, Tyrannidae). Biota Neotropica. 15(2): e20130075. http://dx.doi.org/10.1590/1676-06032015007513

\begin{abstract}
The Gray-backed Tachuri (Polystictus superciliaris) is a Tyrannidae restricted to eastern Brazilian highlands. Its population and range are still thought to be declining mainly due to habitat loss, caused by land use. We evaluated the impacts on its range (increase or decrease, displacement in latitude and altitude), considering possible effects caused by inappropriate land use and climatic changes. For this purpose, we modeled its current range and estimated its overlap between the predicted area and future scenarios. We also analyzed the efficiency of the Brazilian reserves to the species' protection. The range established by the Maxent model was $76.1 \%$ lower than that available in the literature and presented a decrease in the future. Range contraction for the periods under consideration ranged from $22.5 \%$ to $77.3 \%$. The distribution center shifts to the southwest (from $102.5 \mathrm{~km}$ to $275.4 \mathrm{~km}$ ) and to higher elevations (1,102 $\mathrm{m}$ to 1,428 m). From the predicted range, 20\% are under some kind of human occupation. The Brazilian reserves partially protect the species, with only $12 \%$ of its range, from the $44.2 \%$ expected. Based on these predictions, and depending on the species' dispersal ability and adaptation, it may become vulnerable in the period of 2080 . This study demonstrates that the most important areas for maintaining populations of $P$. superciliaris now and in the future are those located in the 'Iron Quadrangle', especially the Serra da Gandarela, where it was partially protected by the recently decreed Gandarela National Park. This region should receive special attention because it is strongly threatened by iron mining in areas relevant for conservation located outside this reserve.
\end{abstract}

Keywords: Climate change, Evaluation reserve efficiency, Espinhaço range, Species distribution model.

HOFFMANN, D., VASCONCELOS, M.F., MARTINS, R.P. Como as mudanças climáticas podem afetar a área de distribuição e o status de conservação de uma ave endêmica das montanhas do leste do Brazil: o caso do papa-moscas-de-costas-cinzentas, Polystictus superciliaris (Aves, Tyrannidae). Biota Neotropica. 15(2): e20130075. http://dx.doi.org/10.1590/1676-06032015007513

Resumo: O papa-moscas-de-costas-cinzentas (Polystictus superciliaris) é uma espécie de Tyrannidae endêmica dos topos de montanha do leste do Brasil. Sua população e área de distribuição estão em declínio principalmente devido à perda de habitat causada pelo uso inadequado da terra. Nós avaliamos os impactos sobre sua distribuição (aumento ou diminuição, deslocamento em latitude e altitude), considerando os possíveis efeitos causados pelo uso do solo e pelas mudanças climáticas. Para esse propósito, modelamos a distribuição atual e avaliamos a sobreposição entre a área predita e os cenários futuros. Também avaliamos a eficiência das Unidades de Conservação brasileiras para a proteção da espécie. A área de distribuição estimada por meio do programa Maxent foi $79,1 \%$ menor que a área encontrada na literatura, apresentando uma tendência a diminuição no futuro. Foi projetada uma contração de $22,5 \%$ a 77,3\% da área de distribuição atual para o futuro. O centro da área de distribuição deslocou-se para o sudeste (de 102,5 a 275,4 km) e para áreas com alta elevação (1.102 m a $1.428 \mathrm{~m})$. Da área projetada, 20\% encontra-se sob algum tipo de ocupação humana. As Unidades de Conservação brasileiras protegem parcialmente a espécie, com somente $12 \%$ de sua distribuição quando o esperado seriam 44,2\%. Baseado nas projeções e, dependendo das habilidades de dispersão e adaptação da 
espécie, ela pode se tornar vulnerável no período de 2080. Este estudo demonstrou que as áreas mais importantes para a manutenção de $P$. superciliaris na atualidade e em períodos futuros situam-se no Quadrilátero Ferrífero, especialmente na Serra da Gandarela, onde parte foi recentemente decretada como Parque Nacional da Gandarela. Essa região deve receber atenção especial por ser altamente ameaçada pela exploração do minério de Ferro e por áreas relevantes continuarem desprotegidas fora da abrangência do novo Parque.

Palavras-chave: Mudanças climáticas, Avaliação da eficiência de Reservas, Cadeia do Espinhaço, Modelos de distribuição de espécies.

\section{Introduction}

Current climatic models predict global warming during the present century (IPCC 2007b). It is likely that the ranges of many species will change drastically (IPCC 2007a). Recent studies have shown that several species are responding to these changes and this pattern tends to increase in the future (e.g. Hughes 2000, Parmesan \& Yohe 2003). Thus, it is expected that these changes will also increase the threat to some species, especially those living at high latitudes and elevations (Millennium Ecosystem Assessment 2005). In this case, largest impacts of climate change are predicted to occur in the high mountain ranges, for example, in the Alps (Beniston et al. 1997, Hughes 2000, Sérgio 2003). This would occur because species living in mountains tend to be more sensitive to climatic changes and present limited ability to adjust their ranges because of the decreasing of available surface with the increasing of elevation (Thuiller et al. 2005, Rull \& Vegas-Vilarrúbia 2006, Pauli et al. 2007).

In this way, it is essential to predict effects and potential management strategies for these species by developing practices aiming to measure how they can be affected by these changes (Jiguet et al. 2010). Aiming the projection of the future suitable range of several species and possible impacts of climatic change on them, several modeling algorithms have been used to define the relationship between the current range of species and the current climatic variables (Thuiller et al. 2005, Heikkinen et al. 2006, Virkkala et al. 2008).

Several authors have assessed the potential impacts of climate change on Neotropical birds (e.g. Anciães \& Peterson 2006, Nunes et al. 2007, Marini et al. 2009b, a, Marini et al. 2010). Nevertheless, studies focusing birds endemic to highaltitude areas are very scarce and restricted to the Andean region (e.g. Graham et al. 2010, Şekercioglu et al. 2012).

In this respect, eastern Brazilian mountains are located between two important global and highly threatened hotspots: the Atlantic Forest and the Cerrado (Silva \& Bates 2002, Mittermeier et al. 2004). These mountains are also considered important centers of diversity and endemism of plants (Giulietti et al. 1997, Safford 1999) and animals (Rodrigues 1988, Stattersfield et al. 1998, Vasconcelos 2008). One of these endemic species is the Gray-backed Tachuri (Polystictus superciliaris), a bird from the family Tyrannidae, which occurs from central Bahia state to northern São Paulo state (Vasconcelos et al. 2003, Vasconcelos 2008). This species lives in the 'campos rupestres' (rocky fields) and 'campos de altitude' (high altitude grasslands), between $950 \mathrm{~m}$ and 1,950 m (Sick 1997, Stattersfield et al. 1998, Vasconcelos et al. 2003). Gray-backed Tachuri populations are thought to be declining due to its restricted range associated to habitat loss (Stattersfield et al. 1998, Vasconcelos et al. 2003, BirdLife International 2014). Nevertheless, the species' known range presented in the basic literature and used to infer its current conservation status (see Ridgely \& Tudor 2009) does not include several localities where it has recent confirmed records (Vasconcelos et al. 2003, Vasconcelos 2008), and includes many areas where conditions are not propitious to its occurrence (e.g., lowlands, forests, and degraded areas), based on our field observations. This is due to the methodology employed by those authors, which basically consists on the union of localities (points) where the species has been recorded, which creates a range. This usually includes deviations of species' ranges, because it is restricted to mountaintops, without records in adjacent lowlands. For an example in the case of the Gray-backed Tachuri, compare the figure with species' range presented by Ridgely \& Tudor (2009) to figure 5 of Vasconcelos (2008).

For species with restricted ranges, including most of the mountaintops endemics, habitat loss is the main factor influencing populations decline and their vulnerabilities (Davies et al. 2009). Knowledge on the impacts of climatic changes and habitat loss on such species is essential to understand how they may persist in the future, specially in regions facing rapid socio-economic development (Pressey et al. 2007), such as Eastern Brazil. Thus, range assessment is important for endemic species, such as the the Gray-backed Tachuri, for which there is little information and, therefore, is likely to become threatened in the future. Furthermore, this approach is also important to assess its conservation status (Anderson \& Martínez-Meyer 2004, Hernandez et al. 2006) and also to determine its actual level of threats and protection (Fuller et al. 2006). In this context, such procedures may contribute to the correct management and successful application of resources for conservation, which are usually scarce.

Under this perspective, we inferred the current and the future ranges with suitable conditions for the Gray-backed Tachuri, in order to assess possible impacts of climatic changes and find new areas with favorable conditions for its occurrence outside its known range, which can be used to guide the application of resources for its conservation. We also evaluated the percentage of its range that coincides with current protected areas (based on available database of reserves decreed until 2011), to determine the need of investments in its protection and to identify possible new areas for its conservation, since it is possible that the species is not fully protected by not occurring in several reserves. Thus, we expect to provide new information for the protection of the Gray-backed Tachuri and its habitat preservation, in order to prevent that this endemic bird will be among the endangered species in the near future.

\section{Materials and Methods}

\section{Species occurrence locations}

In order to determine the localities of occurrence for the Gray-backed Tachuri, we used records obtained by specimens deposited in museums, literature review and our own field 
records (see Vasconcelos 2008, Vasconcelos \& Rodrigues 2010 for sources). Geographic coordinates from museum specimens were obtained from the collection sites listed in their original labels or based on Paynter Jr. \& Traylor Jr. (1991) and Vanzolini (1992). All records with geographic coordinates were plotted within a grid of 30 " cells $\left(\sim 0.833 \times 0.833 \mathrm{~km}^{2}\right)$. Duplicate records within a single cell were removed.

\section{Environmental dataset and climatic change scenarios}

We discarded variables highly correlated and used the six remainder bioclimatic variables of temperature and precipitation for projections of current and future ranges with suitable conditions. These variables were: minimum temperature of the coldest month, maximum temperature of the warmest month, mean annual temperature, annual precipitation, precipitation of the driest month and precipitation of the wettest month. The dataset was obtained from WorldClim (Hijmans et al. 2005), based on interpolations of observed data, representative of 1950-2000. We also used three topographic variables (slope, aspect and compound topographic index), obtained from the database of the US Geological Survey's Hydrolk base 'http://eros.usgs.gov/'). Soil data was obtained from FAO (1998). Vegetation layers were not included in the models because they are not available for future scenarios. All variables used for species distribution model (current and future periods) were standardized to the resolution of 30 " over into the Brazilian's political limits.

For future projections, we used the same variables for each period (2020, 2050 and 2080), by considering three General Circulation Models of gases (GCMs) (CCMA, HADCM3 and CSIRO) and two scenarios of the Special Report Emissions Scenarios (SRES) of the IPCC (2007a) (A2a e B2a), which reflect the potential impacts of different possible demographic, socio-economic and technological developments in the emission of greenhouse gases.

\section{Distribution modeling}

We used Maxent version 3.2.19 with the default setting (Phillips et al. 2006) to model current and future potential suitable ranges for the Gray-backed Tachuri. The projection of current distribution was generated using $75 \%$ of occurrence records randomly selected and evaluated with the remaining $25 \%$. The models were evaluated using an area under the relative operating characteristic curve (AUC/ROC) (Fielding \& Bell 1997). The curve considers the rate of failure in relation to the predicted fractional area. The data were divided this way five times and it was calculated the average AUC with a more robust estimate of the predictive performance. We used all available data to obtain the final distribution range projection.

For the projection of the suitable range for the Graybacked Tachuri, in each of the three future periods, we obtained a consensus among six projections (three GCMs $\mathrm{x}$ two SRES scenarios), maximizing the accuracy and achieving a central trend. To transform the probabilistic ranges (present and future) in a binary map of presence/absence, we selected a threshold value that would encompass all sites (Pearson et al. 2007). Thus, we considered the possibility of $5 \%$ error in the forecast, because, occasionally, some records could represent individuals outside of its optimal niche or in transitional areas. All cells below the threshold value were set to ' 0 ' and kept the probability of occurrence of the above. The area was calculated by summing all pixels that presented the average probability of conditions higher than ' 0 ' among the six projections of presence and absence. Finally, we removed from the predicted areas the overlapping lands already converted into intensive agriculture, urban areas and water bodies, using a land cover map presented by Eva et al. (2002).

In order to analyze the responses of the Gray-backed Tachuri to the climatic changes based on its range, we evaluated the extension and central point (centroid of its range) of predicted range in future periods. The distribution range was calculated by summing all pixels above the threshold value. To assess whether there was range shift, we calculated the distance between the centers of current and future ranges.

For each period, we estimated the ratio between the size of the future and current range, as a measurement of potential impact of climatic changes. This estimate assumes that the species is able to disperse from its present range to a predicted range in the future, without any environmental or physiological impairment (hypothesis of total dispersion). We also calculated the percentage of overlap of the range of each future period in relation to the present, which assumes that the species is unable to disperse into new areas and may occupy only those areas with favorable current conditions and that are predicted in the future as climatically favorable (hypothesis of null dispersion).

To assess whether there was an altitudinal shift, we calculated the difference between the average elevation of the future range projected for each period and the current projection. In this case, the altitude was extracted from all pixels of the predicted range by overlapping a relief map from the US Geological Survey's Hydrolk base (http://eros.usgs. gov/) for subsequent calculation of its average.

\section{Reserves data set and species representation}

Data on the distribution of protected areas in Brazil were obtained from the databases available in ICMBio (http:// www4.icmbio.gov.br). This database consists of about 1,000 federal, state and municipal reserves, implemented until 2006 (equivalent to reserves of category II of IUCN) (MMA 2006). We performed gap analyzes, considering the projection of the current suitable range for the Gray-backed Tachuri and projections for future periods. For each period, an analysis was performed with all reserves. The predicted suitable range was overlapped with reserves distribution and we calculated the percentage of this range found in the protected area. We followed the methods proposed by Rodrigues et al. (2004) and Catullo et al. (2008) in order to identify a representation target (Scott et al. 1993), depending on the extent of the predicted suitable range for the species. Representation is the amount of the range of a species within protected areas, a parameter commonly used in conservation plans to evaluate the need for protection. Analyses were performed considering the following representation targets: i) species with restricted range (area of potential presence less than $1,000 \mathrm{~km}^{2}$ ), which should be protected in $100 \%$ of its range; ii) widespread species (area of potential presence larger than $250,000 \mathrm{~km}^{2}$ ), which should be protected in $10 \%$; and iii) species with an area of potential presence of more than $1,000 \mathrm{~km}^{2}$ and less than $250,000 \mathrm{~km}^{2}$, which should have a representation target obtained by interpolation between the two extremes, using a linear regression of log-transformed area of potential presence 
(Rodrigues et al. 2004). A total gap occurs when a species is not represented in any reserve, a partial gap occurs when a species is represented only partially, and the species is considered covered when the representation target is fully met (Catullo et al. 2008). Representation under climate change was evaluated considering total and null capacity of dispersion (for each scenarios, present, 2020, 2050 and 2080).

\section{Results}

To model the potential distribution, we used 41 spatially independent points of occurrence of the Gray-backed Tachuri. The accuracy of the distribution model in predicting favorable conditions for the presence of the Gray-backed Tachuri was better than random. The AUC mean, based on test data generated from five models, was 0.993 (SD 0.007) and the selected cumulative threshold was 57 . The omission range of the test data was 0.08 (SD 0.11) and the fractional predicted area was 0.003 .

\section{Current distribution}

The predicted current distribution of the Gray-backed Tachuri, with favorable conditions, was $30,745 \mathrm{~km}^{2}$ (Figure 1). This range was $76.1 \%$ lower than that presented by the literature $\left(129,012 \mathrm{~km}^{2}\right)$ (Ridgely \& Tudor 2009) (Figure 2a) and $90.2 \%$ lower than that used to it conservation status assessment $\left(314,000 \mathrm{~km}^{2}\right.$ ) (BirdLife International 2014). The range with natural vegetation currently available for the species was $25,240 \mathrm{~km}^{2}$, not considering those areas converted by intensive agriculture, urban areas and water bodies $\left(5,505 \mathrm{~km}^{2}\right)$.

\section{Distribution in future scenarios}

The suitable range for the Gray-backed Tachuri exhibited a contraction for future periods in relation to present range with favorable conditions. Under the null hypothesis of dispersion for the 2080 period, only a fifth of the current range remains (Figures 2b-d). Considering the hypothesis of total dispersion, the decrease in the current distribution for 2080 was of $64.7 \%$ (Table 1). Under the null hypothesis of dispersion, the range decrease was of $77.3 \%$.

The range shift in future periods showed a gradual increase until 2080. This displacement was of $275.4 \mathrm{~km}$ under the total dispersion hypothesis and of $250.7 \mathrm{~km}$ considering the null hypothesis of dispersion. In addition, we obtained an altitudinal shift average of $325.5 \mathrm{~m}$ and $275.1 \mathrm{~m}$, considering the two hypotheses, respectively (Table 1). For all future periods, the distribution center showed a shift toward the southwest (Figures 2b-d).

\section{Coverage by the National System of Conservation Units (SNUC)}

The predicted area with favorable conditions for the presence of the Gray-backed Tachuri reached 27 to 42 reserves (current and future scenarios). Those reserves protect a total area that ranges from $7,248 \mathrm{~km}^{2}$ to $9,635 \mathrm{~km}^{2}$, depending on the specific scenario (Table 2). Nevertheless, only $49 \%$ of this area presented suitable environments for the species' occurrence (Table 2) and represented only $11.7 \%$ of the predicted current range, from an expected range of at least, $44.2 \%$ (Table 1 ).
Similarly, in future periods, it was observed the loss of favorable conditions for up to eight reserves, considering the null hypothesis of dispersion, and the addition of up to 17 new reserves, if we consider the hypothesis of total dispersion (Table 2). Among the reserves that had favorable current conditions (27), 19 remained, at least partially, favorable in all future scenarios. Among the 13 reserves predicted by the model that have records for the species, 12 partially remained suitable conditions for all future periods (Table 3 ). The majority of the reserves showed a decrease in their areas of potential occurrence for the species in relation to the current scenario. Most affected areas in future scenarios are located in the northern Minas Gerais and Bahia, as is the case of the Morro do Chapéu State Park (Bahia), Biribiri State Park and Sempre Vivas National Park (Minas Gerais), which showed extinction conditions for 2080 (Table 3).

\section{Discussion}

\section{Current predicted distribution}

Recents records support our projections of current suitable range for the Gray-backed Tachuri, considering that these new records made on Caparaó National Park (Costa 2011) and Serra dos Órgãos National Park (Rennó 2012) were not used in the models, and were predicted by these (Figures $2 b-d$, fine and isolated areas).

The predicted current suitable range for the Gray-backed Tachuri showed to be $75 \%$ lower than that presented by the literature (Ridgely \& Tudor 2009) (Figure 2a). Probably the range of this species will prove to be even lower if vegetation is considered. This is because some sites where the soil is deeper and more fertile are covered by forest patches, and because deforestation is a dynamic process that can negatively affect the extent of projected occurrence for future scenarios. This difference may be related to the methods employed by these authors, which are similar to the minimum convex polygon (Odum \& Kuenzler 1955), that consists in the union of all points of occurrence in a polygon, not taking into account the habitat preferences of species. Thus, many areas with unfavorable conditions may be considered favorable. Both hatched areas presented in Figure 2a can be explained because there were only two isolated sets of points at the time of delimitation of the specie's range, which suggested two disjunct populations. Nevertheless, recent surveys have shown that this species is distributed throughout the entire Espinhaço Range, from its southern portion 'Iron Quadrangle' to its northern end, known as the Chapada Diamantina, and also in the Serra da Canastra, to the west, and part of Serra da Mantiqueira and Serra do Mar Ranges, to the south (Vasconcelos et al. 2003, Vasconcelos \& D'Angelo Neto 2007, Vasconcelos 2008, Vasconcelos \& Rodrigues 2010). Costa et al. (2010) reported a genetic isolation between specimens of two areas that in current predicted range are isolated by physical barriers corresponding to lowland areas. In this context and based on the current predicted range we were able to identify seven possible populations may be isolated in the eastern Brazilian highlands by lowland barriers (Figure 1). Therefore, further phylogeographic studies and information on the ability of transposition of unfavorable areas by the species are necessary to assess if there is interruption of gene flow by these other possible barriers. 


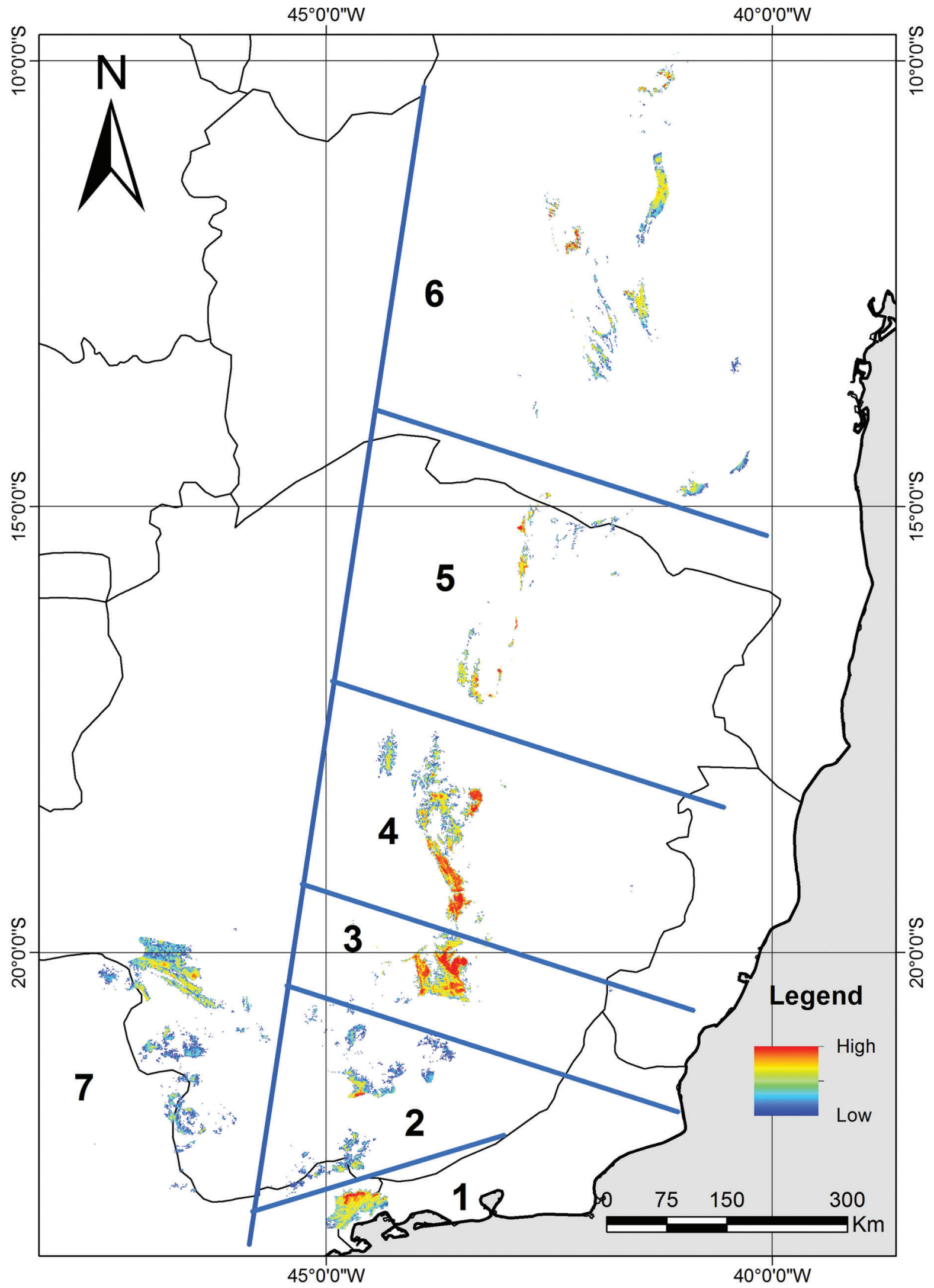

Figure 1. Current predicted distribution of the Gray-backed Tachuri (Polystictus superciliaris). The color scale represents the probability of favorable conditions within each pixel above the threshold of sensitivityspecificity, from lower (light blue) to highest (red). White areas are below the favorable conditions. Lines represent possible geographical natural barriers to the dispersal of the species and probably dividing isolated subpopulations (numbers). 

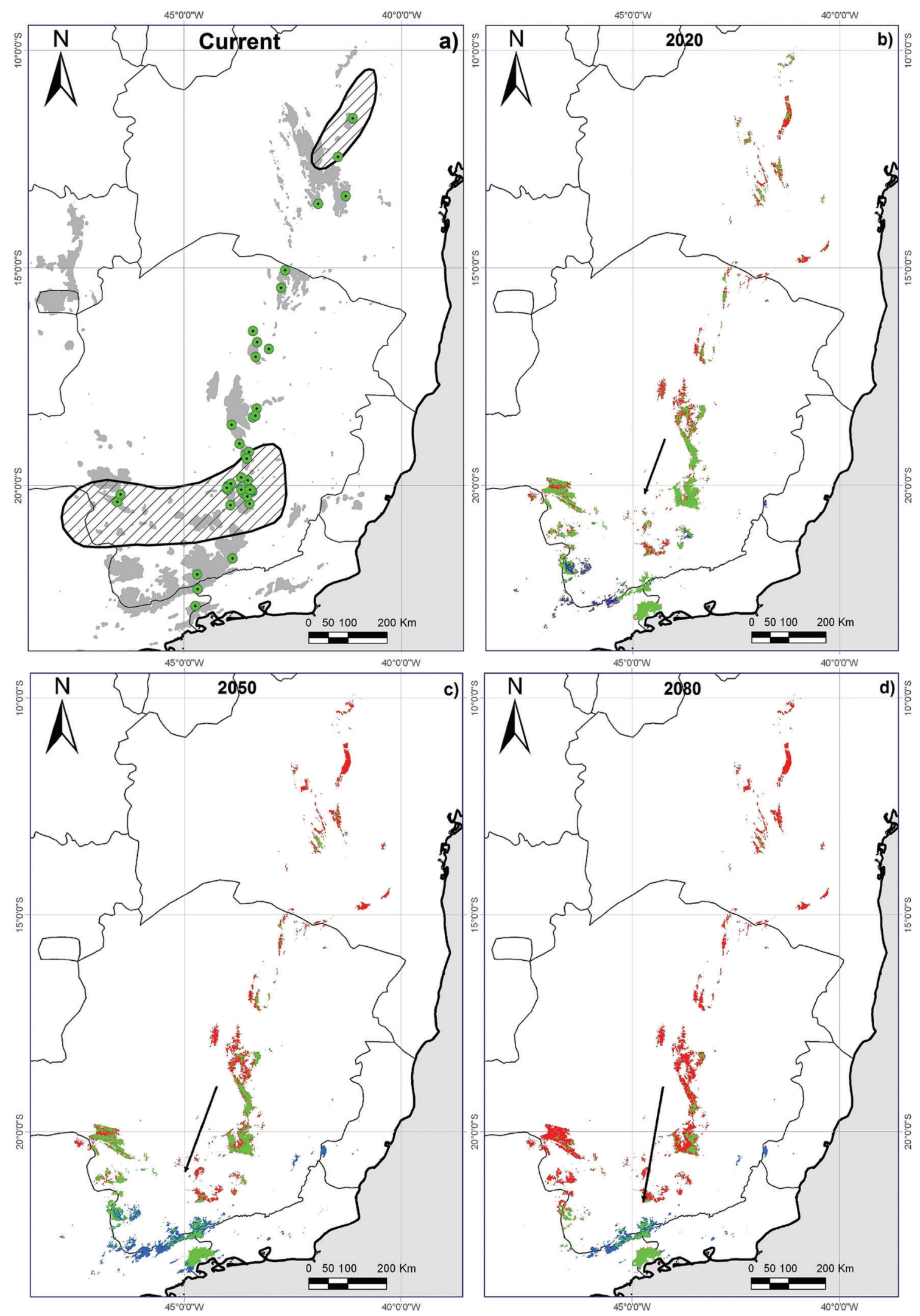

Figure 2. (a) Range of the Gray-backed Tachuri (Polystictus superciliaris) (shaded area) following Ridgely \& Tudor (2009) and real distribution based on museum specimens, literature and fieldwork (points); altitudes above 1,000 m are represented in gray; (b-d) area with constant favorable conditions (current and future periods) for the presence of the Gray-backed Tachuri (green), potential area for future occupation/dispersal but not currently (blue), current area with the possibility of loss of favorable conditions (red) in future periods (2020, 2050 and 2080, respectively) and shift of distribution center in relation to the current distribution (black arrows). 
Table 1. Estimation of the distribution of the Gray-backed Tachuri (Polystictus superciliaris) for current and future periods; predicted area currently impacted; expected level of effective protection in reserves; variation in size and loss of area; direction and displacement of the area centroid and altitudinal shift in future periods in relation to the present, under the assumptions of the hypothesis of total dispersion and the null hypothesis of dispersion.

\begin{tabular}{|c|c|c|c|c|c|c|c|c|}
\hline & $\begin{array}{c}\text { Projected } \\
\text { range }\left(\mathrm{km}^{2}\right)\end{array}$ & $\begin{array}{l}\text { Used area } \\
\text { within range } \\
\left(\mathrm{km}^{2}\right)\end{array}$ & $\begin{array}{l}\text { Protected area } \\
\text { expected }(\%)\end{array}$ & $\begin{array}{l}\text { Protected area in } \\
\text { all reserves }(\%)\end{array}$ & $\begin{array}{l}\text { Loss of } \\
\text { range }(\%)\end{array}$ & $\begin{array}{l}\text { Range } \\
\text { shift } \\
(\mathbf{k m})\end{array}$ & $\begin{array}{l}\text { Altitudinal } \\
\text { shift (m) }\end{array}$ & $\begin{array}{l}\text { Range } \\
\text { shift } \\
\text { direction }\end{array}$ \\
\hline & & & & \multicolumn{5}{|l|}{ With dispersion } \\
\hline Current & 30,745 & 5,505 & 44.2 & 11.7 & $*$ & $*$ & * & $*$ \\
\hline 2020 & 22,247 & 4,178 & 49.4 & 13.1 & 27.6 & 138 & 126 & Southwest \\
\hline 2050 & 23,837 & 3,937 & 48.3 & 13.8 & 22.5 & 216 & 186 & Southwest \\
\hline 2080 & 10,837 & 851 & 61.2 & 17.0 & 64.8 & 275 & 326 & Southwest \\
\hline & & & & \multicolumn{5}{|c|}{ Without dispersion } \\
\hline Current & 30,745 & 5,505 & 44.2 & 11.7 & $*$ & $*$ & $*$ & $*$ \\
\hline 2020 & 19,036 & 3,268 & 52.0 & 13.8 & 38.1 & 103 & 110 & Southwest \\
\hline 2050 & 15,537 & 2,589 & 55.3 & 15.5 & 49.5 & 170 & 136 & Southwest \\
\hline 2080 & 6,986 & 649 & 68.3 & 17.0 & 77.3 & 251 & 275 & Southwest \\
\hline
\end{tabular}

Table 2. Number of reserves with high suitability for the occurrence of the Gray-backed Tachuri (Polystictus superciliaris) at present and in future periods, considering the variation in the extent of the area, the total area of reserves and percentage of area represented.

\begin{tabular}{|c|c|c|c|c|c|c|c|}
\hline & \multirow[t]{2}{*}{ Present } & \multicolumn{3}{|c|}{ With dispersion } & \multicolumn{3}{|c|}{ Without dispersion } \\
\hline & & 2020 & 2050 & 2080 & 2020 & 2050 & 2080 \\
\hline Number of reserves & 27 & 30 & 42 & 30 & 26 & 25 & 19 \\
\hline Reserves with decrease of range & 0 & 16 & 16 & 10 & 16 & 16 & 10 \\
\hline Reserves with increase of range & 0 & 5 & 7 & 7 & 5 & 7 & 7 \\
\hline Reserves that have lost conditions & 0 & 1 & 2 & 8 & 1 & 2 & 8 \\
\hline Reserves added & 0 & 4 & 17 & 11 & 0 & 0 & 0 \\
\hline Reserves in which the range remain constant & 0 & 5 & 2 & 2 & 5 & 2 & 2 \\
\hline Reserves areas $\left(\mathrm{km}^{2}\right)$ & 7,248 & 7,558 & 9,635 & 7,494 & 7,230 & 6,828 & 5,216 \\
\hline$\%$ of suitable areas in the reserves & $49 \%$ & $39 \%$ & $34 \%$ & $25 \%$ & $26 \%$ & $24 \%$ & $12 \%$ \\
\hline Representation in the reserves $\left(\mathrm{km}^{2}\right)$ & 3,586 & 2,924 & 3,292 & 1,839 & 2,628 & 2,403 & 1,188 \\
\hline
\end{tabular}

\section{Projected distribution in future scenarios}

Climatic change may be an important driver for range reduction of several species (IPCC 2007a). The conversion of natural vegetation into antropic areas is a dynamic process along time (see Silva et al. 2006), being responsible for the loss of approximately $1 / 5$ of the current range projected. Even with the extinction of these activities, our results predicted a decrease of $38.1-77.3 \%$ of the current species range.

The center of distribution of the Gray-backed Tachuri showed a gradual latitudinal shift southwestward. It also presented an altitudinal shift. These results showed that this species responds similarly to other montane species (e.g., Bussche et al. 2008, Popy et al. 2010), which tend to occupy higher areas and/or to move to higher latitudes, with temperature increase. Parmesan \& Yohe (2003) considered that each $1 \mathrm{~km}$ of latitudinal displacement in the range would be equivalent to the displacement of $1 \mathrm{~m}$ in altitude. The model of distribution of the Gray-backed Tachuri partially showed this pattern, or was close to it. The shift of the species' distribution Center toward southwest coincides with this predictable hypothesis, since displacement vectors were directed to the highland areas of Espinhaço and Mantiqueira Ranges (Figure 2b-d).

In a recent gap analysis, Marini et al. (2009a) found a larger area for the current distribution $\left(55,000 \mathrm{~km}^{2}\right)$ of the Gray-backed
Tachuri in comparison to that observed in the present study $\left(30,745 \mathrm{~km}^{2}\right)$. Similar discrepancies can also be observed for the extent of the impacted area $\left(13000 / 5505 \mathrm{~km}^{2}\right)$ and available range $\left(420000 / 25240 \mathrm{~km}^{2}\right)$. This difference may be related to the fact that Marini et al. (2009a) have used a larger number of algorithms and/or due a coarser resolution (of $4.5 \times 4.5 \mathrm{~km}^{2}$ ), which covers more unfavorable areas that were considered in the present analysis. Despite these methodological differences, a decrease in the range of the Gray-backed Tachuri in future periods is clear in both studies, as the representation of the species range in protected areas, is lower than expected. The response of the species to future climate change will depend on the availability of shrubby environments where it feeds and nests, and from the shrubby vegetation response by climate change (Hoffmann et al. 2007, Hoffmann \& Rodrigues 2011) and/or on its ability to adapt to new environmental conditions.

\section{Conservation and protection by the Brazilian system of conservation units (SNUC)}

Among all reserves where the Gray-backed Tachuri has been recorded $(\mathrm{n}=14)$ (M.F. Vasconcelos, unpublished data), $85 \%(n=12)$ were predicted by the model. Other 15 reserves were predicted to have favorable conditions in the present and in future periods and they present shrubby vegetation that is 


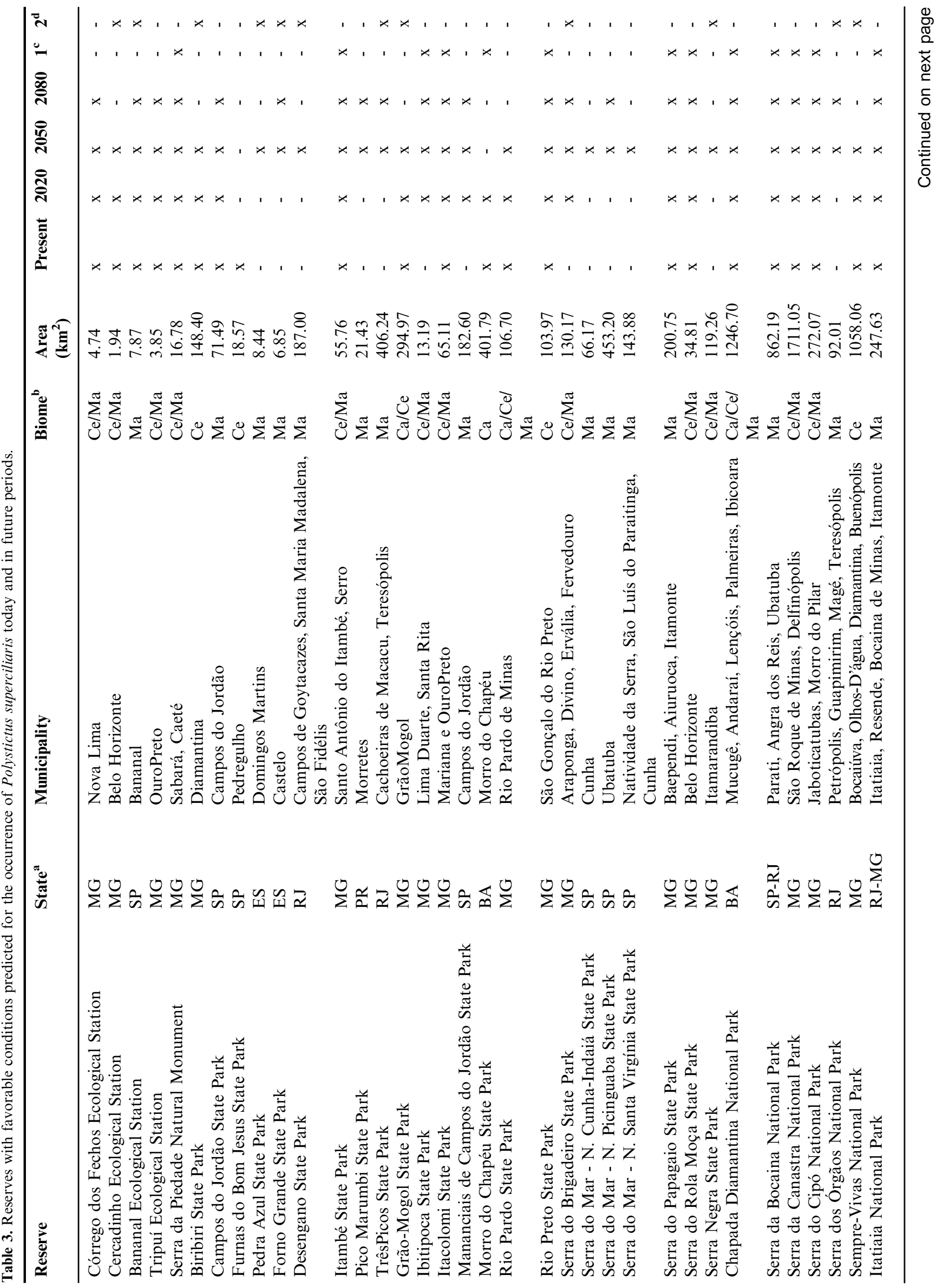




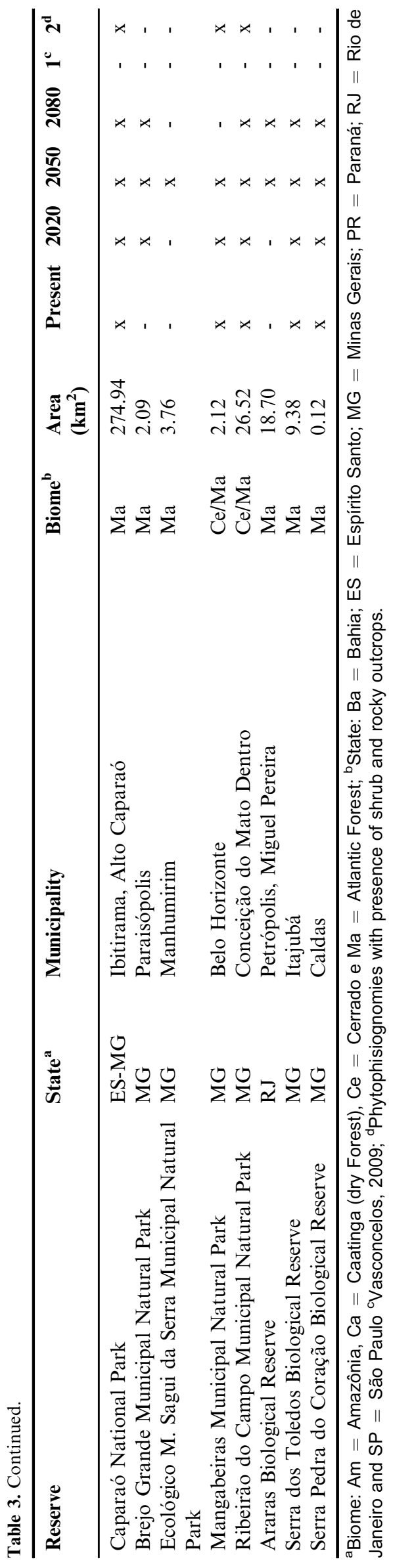

favorable to the species (M.F. Vasconcelos, unpublished data) (Table 3). However, the species has not been recorded in these locations because of the lack of avifaunal surveys, or even because of its inability to colonize these areas through lowland barriers (Chaves et al. 2014).

Currently, the species is found in reserves with more than $1,000 \mathrm{~km}^{2}$, such as the Serra da Canastra and the Chapada Diamantina National Parks $\left(1,711 \mathrm{~km}^{2}\right.$ and $1,246 \mathrm{~km}^{2}$, respectively), but also in small reserves, with less than $20 \mathrm{~km}^{2}$, as in the case of Ibitipoca State Park and Serra da Piedade Natural Monument ( $13 \mathrm{~km}^{2}$ and $16 \mathrm{~km}^{2}$, respectively). However, small reserves may not have enough area to maintain viable populations of the Gray-backed Tachuri, estimated as about $200 \mathrm{~km}^{2}$ (Hoffmann 2011). Disregarding the reserve size, the Gray-backed Tachuri appeared to be less abundant in the north of its range (M.F. Vasconcelos, unpublished data), which includes the Chapada Diamantina National Park. Thus, one of the largest reserves with predicted occurrence has a low efficiency for the species' conservation.

The representation of the Gray-backed Tachuri in reserves is only one-quarter of the expected for the present and tends to decrease gradually in future periods due to range reduction. The percentage of the predicted range represented in the reserves, for considering the species protected, increased gradually in future periods. Thus, there was a decrease of the total predicted range and, consequently, the need for increasing the species' representation for, at least, 61.2 and $68.3 \%$, considering the hypothesis of total dispersion and the null hypothesis of dispersion, respectively (Table 1). The decrease in the species' representation indicates that the reserves that currently present suitable habitat will become inefficient and inadequate for the species' conservation under future scenarios of environmental changes.

The distribution models as those generated by Maxent, could act as important tools for understanding many aspects of current and future predicted suitable ranges for the Graybacked Tachuri, providing important information to re-evaluate its conservation status and ideas for possible conservation plans, as well as subsidizing important questions about the species, yet to be investigated. An example would be the potential barriers that probably isolate populations, in order to demonstrate the possibility of occupation of new areas in future. Knowledge on the species' ability to cross these potential barriers would be an important indicator of the possibility of colonization of new areas in the face of possible climatic changes, considering that there are no reports on the viability of translocation and reintroduction programs for small and exclusively insectivorous tyrant-flycatchers (Tyrannidae). The region where the environmental suitability for the Gray-backed Tachuri remained constant in future periods, with a great area extension, is located in the 'Iron Quadrangle' region, Minas Gerais. This region has been strongly impacted by iron mining with more than 50 iron-ore opencast mines that totalize c. 2000 ha (DNPM Departamento Nacional de Produção Mineral 2006, Jacobi et al. 2007), which have caused high destruction of the 'campos rupestres' vegetation.

In order to review the species' conservation status it should be considered, for the estimation of its range, restrictive characteristics of its localities of occurrence (e.g. altitudinal limit and climatic variables), and not only the delineation of an area that incorporates all records of occurrence. The range of the Gray-backed Tachuri used in the assessment of its 
conservation status in 2008 was $104,000 \mathrm{~km}^{2}$ and tripled $\left(314,000 \mathrm{~km}^{2}\right)$ for the revaluation in 2011 , lowering the species' status from 'near-threatened' to 'least concern' (BirdLife International 2014). The present results contradict this new categorization, indicating that the conservation status of many species, mainly based on their ranges, may be influenced by factors not considered limiting of their occurrence. Thus, we consider that the species should remain as 'near-threatened' and, if the impacts of climatic changes really occur, the species should be included in the 'vulnerable' category according to the B1 criterion $\left(<20,000 \mathrm{~km}^{2}\right)$ of IUCN (2001).

The species had a projected range on the political boundaries of five Brazilian states: São Paulo, Minas Gerais, Rio de Janeiro, Espírito Santo and Bahia. Nevertheless, it is not endangered in any regional threatened category in the first four states that present regional red lists (Bergallo et al. 2000, Biodiversitas 2007, Passamani \& Mendes 2007, Bressan et al. 2009). The northern range of the species is located in Bahia, a state that does not have any red list. Furthermore, the fact that the species is not represented on a list of threatened species at a regional level should be viewed with caution, since the species was recorded in the states of Rio de Janeiro and Espírito Santo after the publication of the red lists of those states. In both states there is evidence that populations of Gray-backed Tachuri are very small and present restricted range. On the other hand, in the state of São Paulo there are historical records of the species and an absence of recent records. Thus, the extent of occurrence of the species presented in this paper is also important for the assessment and reassessment of the conservation status of the species at regional levels.

Finally, we suggest investing in research on autoecology and natural history of this and other species that are virtually unknown in the Neotropics. This information may help improve the models prediction and are essential for the conservation of the Gray-backed Tachuri and probably the entire highland biota from eastern Brazil.

\section{Acknowledgments}

We are grateful to the Coordenação de Aperfeiçoamento de Pessoal de Nível Superior for the support to D. Hoffmann and M.F. Vasconcelos with PhD grants. M.F. Vasconcelos was also supported by a collection study grant from the American Museum of Natural History. Three anonymous reviewers made important criticism on the original manuscript.

\section{References}

ANCIÃES, M. \& PETERSON, A.T. 2006. Climate change efects on Neotropical manakin diversity based on ecological niche modeling. Condor 108:778-791.

ANDERSON, R.P. \& MARTÍNEZ-MEYER, E. 2004. Modeling species geographic distributions for preliminary conservation assessments: an implementation with the spiny pocket mice (Heteromys) of Ecuador. Biol. Conserv. 116(2):167-179. http://dx. doi.org/10.1016/S0006-3207(03)00187-3.

BENISTON, M., DIAZ, H.F. \& BRADLEY, R.S. 1997. Climate change at high elevation sites: an overview. Clim. Change 36: 233-251.

BERGALlO, H.G., ROCHA, C.F.D., ALVES, M.A.S. \& VAN SLUYS, M. 2000. A fauna ameaçada de extinção do Estado do Rio de Janeiro. Editora Universidade do Estado do Rio de Janeiro, Rio de Janeiro, RJ.
BIODIVERSITAS 2007. Revisão das listas das espécies da flora e da fauna ameaçadas de extinção do estado de Minas Gerais. Biodiversitas, Belo Horizonte.

BIRDLIFE INTERNATIONAL. 2014. Species factsheet: Polystictus superciliaris. www.birdlife.org. (last access in 30/05/2014).

BRESSAN, P.M., KIERULFF, M.C.M. \& SUGIEDA, A.M. 2009. Fauna ameaçada de extinção no Estado de São Paulo: Vertebrados. Secretaria do Meio Ambiente, São Paulo.

BUSSCHE, J., SPAAR, R., SCHMID, H. \& SCHRÖDER, B. 2008. Modelling the recent and potential future spatial distribution of the ring ouzel (Turdus torquatus) and blackbird (T. merula) in Switzerland. J. Ornithol. 149:529-544. http://dx.doi.org/10.1007/ s10336-008-0295-9.

CATUllo, G., MASI, M., FALCUCCI, A., MAIORANO, L., RONDININI, C. \& BOITANI, L. 2008. A gap analysis of Southeast Asian mammals based on habitat suitability models. Biol. Conserv. 141:2730-2744. http://dx.doi.org/10.1016/j.biocon. 2008.08.019.

CHAVES, A.V., FREITAS, G.H.S., VASCONCELOS, M.F. \& SANTOS, F.R. 2014. Biogeographic patterns, origin and speciation of the endemic birds from eastern Brazilian mountaintops: a review. Syst. Biodivers. 12:1-16.

COSTA, F.V. 2011. [WA401055, Polystictus superciliaris (Wied, 1831)]. http://www.wikiaves.com/401055. (last access in 31/05/2014).

COSTA, L.C., NASCIMENTO, A.C.A., CHAVES, A.V., VASCONCELOS, M.F. \& SANTOS, F.R. 2010. Filogeografia de Polystictus superciliaris. In $56^{\circ}$ Congresso Brasileiro de Genética, (SBG, coord.). SBG, Guarujá, SP, p. 82.

DAVIES, T.J., PURVIS, A. \& GITTLEMAN, J.L. 2009. Quaternary climate change and the geographic range of mammals. Am. Nat. 174:297-307. http://dx.doi.org/10.1086/603614.

DNPM-DEPARTAMENTO NACIONAL DE PRODUÇÃO MINERAL 2006. Ferro. Ministério de Minas e Energia, Brasília.

EVA, H.D., MIRANDA, E.E., DI BELLA, C.M., GOND, V., HUBER, O., SGRENZAROLI, M., JONES, S., COUTINHO, A., DORADO, A., GUIMARÃES, M., ELVIDGE, C., ACHARD, F., BELWARD, A.S., BARTHOLOMÉ, E., BARALDI, A., DE GRANDI, G., VOGT, P., FRITZ, S. \& HARTLEY, A. 2002. A vegetation map of South America. Office for Official Publications of the European Communities, Luxembourg.

FAO 1998. Soil and terrain database for Latin America and the Caribbean. FAO, Rome.

FIELDING, A.H. \& BELL, J.F. 1997. A review of methods for the assessment of prediction errors in conservation presence/absence models. Environ. Conserv. 24(1):38-49. http://dx.doi.org/10.1017/ s0376892997000088.

FULlER, T., MUNGUIA, M., MAYFIELD, M., SÁNCHEZCORDERO, V. \& SARKAR, S. 2006. Incorporating connectivity into conservation planning: a multi-criteria case study from Central Mexico. Biol. Conserv. 133:131-142. http://dx.doi.org/10.1016/j. biocon.2006.04.040.

GIULIETTI, A.M., PIRANI, J.R. \& HARLEY, R.M. 1997. Espinhaço range region, eastern Brazil. In Centers of plant diversity: a guide and strategy for their conservation (DAVIS, S.D., Heywood, V.H., Herrera-Macbride, O., Villa-Lobos, J. \& Hamilton, A.C. eds). Information Press, Oxford, v. 3, p. 397-404.

GRAHAM, C.H., SILVA, N. \& VELAZQUEZ TIBATA, J. 2010. Evaluating the potential causes of range limits of birds of the Colombian Andes. J. Biogeogr. 37(10):1863-1875. http://dx.doi. org/10.1111/j.1365-2699.2010.02356.x.

HEIKKINEN, R.K., LUOTO, M., ARAÚJO, M.B., VIRKKALA, R., THUILLER, W. \& SYKES, M.T. 2006. Methods and uncertainties in bioclimatic envelope modelling under climate change. Prog. Phys. Geog. 30:751-777.

HERNANDEZ, P.A., GRAHAM, C.H., MASTER, L.L. \& ALBERT, D. L. 2006. The effect of sample size and species characteristics on performance of different species distribution modeling methods. Ecography 29:773-785. http://dx.doi.org/10.1111/j.0906-7590.2006.04700.x. 
HIJMANS, R.J., CAMERON, S.E., PARRA, J.L., JONES, P.G. \& JARVIS, A. 2005. Very high resolution interpolated climate surfaces for global land areas. Int. J. Climatol. 25:1965-1978. http:// dx.doi.org/10.1002/joc.1276.

HOFFMANN, D. 2011. Distribuição potencial e viabilidade de uma população de Polystictus superciliaris (Aves, Tyrannidae), no sudeste do Brasil. Tese de Doutorado, Universidade Federal de Minas Gerais, Belo Horizonte.

HOFFMANN, D. \& RODRIGUES, M. 2011. Breeding biology and reproductive success of Polystictus superciliaris (Wied, 1831) (Aves: Tyrannidae): an uncommon tyrant-flycatcher endemic to the highlands of eastern Brazil. Zoologia 28(3):305-311. http://dx.doi. org/10.1590/S1984-46702011000300004.

HOFFMANN, D., VASCONCELOS, M.F., LOPES, L.E. \& RODRIGUES, M. 2007. Comportamento de forrageamento e dieta de Polystictus superciliaris (Aves, Tyrannidae) no sudeste do Brasil. Iheringia Ser. Zool. 97(3):296-300. http://dx.doi.org/ 10.1590/S0073-47212007000300014.

HUGHES, L. 2000. Biological consequences of global warming: is the signal already. Trends Ecol. Evol. 15:56-61. http://dx.doi.org/ 10.1016/S0169-5347(99)01764-4.

IPCC 2007a. Climate Change 2007: impacts, adaption and vulnerability, contribution of working group II to the fourth assessment report of the IPCC. Cambridge University Press, Cambridge, UK and New York, USA.

IPCC 2007b.Climate Change 2007: The physical science basis. Contributions of working group I to the fourth assesment report of the intergovernmental panel on climate change Cambridge University Press, Cambridge, UK and New York, USA.

IUCN 2001. IUCN Red List Categories and Criteria: Version 3.1. IUCN Species Survival Commission. IUCN, Gland, Switzerland and Cambridge, UK.

JACOBI, C.M., CARMO, F.F., VINCENT, R.C. \& STEHMANN, J. R. 2007. Plant communities on ironstone outcrops: a diverse and endangered Brazilian ecosystem. Biodivers. Conserv. 16(7): 2785-2200. http://dx.doi.org/10.1007/s10531-007-9156-8.

JIGUET, F., GREGORY, R.D., DEVICTOR, V., GREEN, R.E., VORISEK, P., VAN STRIEN, A. \& COUVET, D. 2010. Population trends of European common birds are predicted by characteristics of their climatic niche. Global Change Biol. 16: 497-505. http://dx.doi.org/10.1111/j.1365-2486.2009.01963.x.

MARINI, M.Â., BARBET-MASSIN, M., LOPES, L.E. \& JIGUET, F. 2009a. Major current and future gaps of Brazilian reserves to protect Neotropical savanna birds. Biol. Conserv. 142(12): 3039-3050. http://dx.doi.org/10.1016/j.biocon.2009.08.002.

MARINI, M.Â., BARBET-MASSIN, M., LOPES, L.E. \& JIGUET, F. 2009b. Predicted climate-driven bird distribution changes and forecasted conservation conflicts in a Neotropical Savanna. Conserv. Biol. 23(6):1558-1567. http://dx.doi.org/10.1111/j.15231739.2009.01258.x.

MARINI, M.Â., BARBET-MASSIN, M., MARTINEZ, J., PRESTES, N.P. \& JIGUET, F. 2010. Applying ecological niche modelling to plan conservation actions for the red-spectacled amazon (Amazona pretrei). Biol. Conserv. 143(1):102-112. http://dx.doi.org/10.1016/j.biocon.2009. 09.009 .

MILLENNIUM ECOSYSTEM ASSESSMENT. 2005. Ecosystems and human well-being: biodiversity synthesis. World Resources Institute, Washington, DC.

MITTERMEIER, R.A., GIL, P.R., HOFFMANN, M., PILGRIM, J. D., BROOKS, J., MITTERMEIER, C.G., LAMOURUX, J. \& FONSECA, G.A.B. 2004. Hotspots revisited: earth's biologically richest and most endangered terrestrial ecoregions. Cemex, Mexico City, México.

MMA 2006. Sistema Nacional de Unidades de Conservação da Natureza - SNUC, lei $\mathrm{n}^{\circ} 9.985$, de 18 de julho de 2000; decreto $\mathrm{n}^{\circ}$ 4.340, de 22 de agosto de 2002. MMA/SBF, Brasília.

NUNES, M.F.C., GALETTI, M., MARSDEN, S., PEREIRA, R.S. \& PETERSON, A.T. 2007. Are large-scale distributional shifts of the blue-winged macaw (Primolius maracana) related to climate change? J. Biogeogr. 34:816-827. http://dx.doi.org/10.1111/j.13652699.2006.01663.x.

ODUM, E.P. \& KUENZLER, E.J. 1955. Measurements of territory and home range size in birds. Auk 72:128-137.

PARMESAN, C. \& YOHE, G. 2003. A globally coherent fingerprint of climate change impacts across natural systems. Nature 421:37-42. http://dx.doi.org/10.1038/nature01286.

PASSAMANI, M. \& MENDES, S.L. 2007. Espécies da fauna ameaçadas de extinção no estado do Espírito Santo. Instituto de Pesquisa da Mata Atlântica, Vitória, ES.

PAUli, H., GOTTFRIED, M., REITER, K., KLETTNER, C. \& GRABHERR, G. 2007. Signals of range expansion and contractions of vascular plants in the high Alps: observationns (1994-2003) at the GLORIA master site Schrankvogel, Tyrol Austria. Global Change Biol. 13:147-156. http://dx.doi.org/10.1111/j.1365-2486. 2006.01282.x.

PAYNTER, JR., R.A. \& TRAYLOR, JR., M.A. 1991. Ornithological gazetteer of Brazil. Museum of Comparative Zoology, Cambridge, Massachusetts.

PEARSON, R.G., RAXWORTHY, C.J., NAKAMURA, M. \& PETERSON, A.T. 2007. Predicting species distributions from small numbers of occurrence records: a test case using cryptic geckos in Madagascar. J. Biogeogr. 34(1):102-117. http://dx.doi. org/10.1111/j.1365-2699.2006.01594.x.

PHILLIPS, S.J., ANDERSON, R.P. \& SCHAPIRE, R.E. 2006. Maximum entropy modeling of species geographic distributions. Ecol. Model. 190:231-259. http://dx.doi.org/10.1016/j.ecolmodel.2005.03.026.

POPY, S., BORDIGNON, L. \& PRODON, R. 2010. A weak upward elevational shift in the distributions of breeding birds in the Italian Alps. J. Biogeogr. 37(1):57-67. http://dx.doi.org/10.1111/ j.1365-2699.2009.02197.x.

PRESSEY, R.L., CABEZA, M., WATTS, M.E., COWLING, R.M. \& WILSON, K.A. 2007. Conservation planning in a changing world. Trends Ecol. Evol. 22:583-592. http://dx.doi.org/10.1016/j.tree. 2007.10.001.

RENNÓ, B. 2012. [WA650076, Polystictus superciliaris (Wied, 1831)]. http://www.wikiaves.com/650076. (last access in 31/05/2014).

RIDGELY, R.S. \& TUDOR, G. 2009. Field guide to the songbirds of South America: the Passerines. University of Texas Press, Austin, TX.

RODRIGUES, A.S.L., AKÇAKAYA, H.R., ANDELMAN, S.J., BAKARR, M.I., BOITANI, L., BROOKS, T.M., CHANSON, J. S., FISHPOOL, L.D.C., FONSECA, G.A.B., GASTON, K.J., HOFFMANN, M., MARQUET, P.A., PILGRIM, J.D., PRESSEY, R.L., AB'SÁBER, A.N., SECHREST, W., STUART, S.N., UNDERHILL, L.G., WALLER, R.W., WATTS, M.E., YAN, X., RODRIGUES, A.S.L., AKCAKAYA, H.R., ANDELMAN, S.J., BAKARR, M.I., BOITANI, L., BROOK, B. W., CHANSON, J.S., FISHPOOL, L.D.C., FONSECA, G.A.B., GASTON, K.J., HOFFMANN, M., MARQUET, P.A., PILGRIM, J.D., PRESSEY, R.L., SCHIPPER, J., SECHREST, W., STUART, S.N., UNDERHILL, L.G., WALLER, R.W., WATTS, M.E.J. \& YAN, X. 2004. Global gap analysis: priority regions for expanding the global protected-area network. Bioscience 54:1092-1100. http://dx.doi.org/10.1641/0006-3568 (2004)054[1092:GGAPRF]2.0.CO;2.

RODRIGUES, M.T. 1988. Distribution of lizards of the genus Tropidurus in Brazil (Sauria, Iguanidae). In Proceedings of a workshop on Neotropical distribution patterns, (Vanzolini, P.E, Heyer, W.R, coord.). Academia Brasileira de Ciências, Rio de Janeiro, p. 305-315.

RULL, V. \& VEGAS-VILARRÚBIA, T. 2006. Unexpected biodiversity loss under global warming in the neotropical Guayana Highlands: a preliminary appraisal. Global Change Biol. 12:1-9. http://dx.doi.org/10.1111/j.1365-2486.2005.01080.x.

SAFFORD, H.D. 1999. Brazilian páramos I. An introduction to the physical environment and vegetation of the campos de altitude. 
J. Biogeogr. 26(4):693-712. http://dx.doi.org/10.1046/j.1365-2699. 1999.00313.x.

SCOTT, J.M., DAVIS, F., CSUTI, B., NOSS, R., BUTTERFIELD, B., GROVES, C., ANDERSON, H., CAICCO, S., D'ERCHIA, F., EDWARDS, JR., T.C., ULLIMAN, J. \& WRIGHT, R.G. 1993. Gap analysis: a geographic approach to protection of biological diversity. Wildl. Monogr. 123:1-41.

ŞEKERCIOGLU, Ç.H., PRIMACK, R.B. \& WORMWORTH, J. 2012. The effects of climate change on tropical birds. Biol. Conserv. 148(1):1-18. http://dx.doi.org/10.1016/j.biocon.2011.10.019.

SÉRGIO, F. 2003. Relationship between laying dates of black kites Milvus migrans and spring temperatures in Italy: rapid response to climate change? J. Avian Biol. 34:144-149.

SICK, H. 1997. Ornitologia brasileira. Nova Fronteira, Rio de Janeiro.

SILVA, J.F., FARIÑAS, M.R., FELFILI, J.M. \& KLINK, C.A. 2006. Spatial heterogeneity, land use and conservation in the cerrado region of Brazil. J. Biogeogr. 33:536-548.

SILVA, J.M.C. \& BATES, J.M. 2002. Biogeographic patterns and conservation in the South American Cerrado: A tropical savanna Hotspot. Bioscience 52(3):225-234.

STATTERSFIELD, A.J., CROSBY, M.J., LONG, A.J. \& WEGE, D.C. 1998. Endemic birds areas of the world: Priorities for biodiversity conservation. BirdLife International, Cambridge, U.K.

THUILlER, W., LAVOREL, S., ARAÚJO, M.B., SYKES, M.T. \& PRENTICE, I.C. 2005. Climate change threats to plant diversity in Europe. Proc. Natl. Acad. Sci. U. S. A. 102: $8245-8250$.

VANZOLINI, P.E. 1992. A Supplement to the Ornithological Gazetteer of Brazil. Museu de Zoologia, Universidade de São Paulo, São Paulo.

VASCONCELOS, M.F. 2008. Mountaintop endemism in eastern Brazil: why some bird species from campos rupestres of the Espinhaço Range are not endemic to the cerrado region? Rev. Bras. Ornitol. 16(4):348-362.

VASCONCELOS, M.F. \& D'ANGELO NETO, S. 2007. Padrões de distribuição e conservação da avifauna na região central da Cadeia do Espinhaço e áreas adjacentes, Minas Gerais, Brasil. Cotinga 28:27-44.

VASCONCELOS, M.F., MALDONADO-COELHO, M. \& BUZZETTI, D.R.C. 2003. Range extension for the gray-backed tachuri (Polystictus superciliaris) and the pale-throated serra-finch (Embernagra longicauda) with the revision on their geographic distribution. Ornitol. Neotrop. 14(4):477-489.

VASCONCELOS, M.F. \& RODRIGUES, M. 2010. Patterns of geographic distribution and conservation of the open-habitat avifauna of southeastern Brazilian mountaintops (Campos rupestres and Campos de altitude). Pap. Avulsos Zool. (São Paulo) 50(1):1-29.

VIRKKALA, R., HEIKKINEN, R.K., LEIKOLA, N. \& LUOTO, M. 2008. Projected large-scale range reductions of norhtern-boreal land bird species de to climate change. Biol. Conserv. 141: 1343-1353. http://dx.doi.org/10.1016/j.biocon.2008.03.007. 